\title{
当院における腹腔鏡下仙骨胵固定術に対する取り組み
}

新百合ヶ丘総合病院産婦人科 ${ }^{11}$ 、新川崎こびきウィメンズクリニック ${ }^{21}$

永井 崇 ${ }^{1)}$ 、別宮若菜 ${ }^{1)}$ 、向田幸子 ${ }^{1)}$ 、佐々 木恵子 ${ }^{1)}$ 、益子尚子 ${ }^{1)}$ 、中村浩敬 ${ }^{1)}$ 、

奥野さつき ${ }^{1)}$ 、佐藤美和 ${ }^{1)}$ 、浅井 哲 ${ }^{1)}$ 、原 周一郎 ${ }^{1)}$ 、塚田ひとみ ${ }^{1)}$ 、竹本周二1) 、 田島博人 ${ }^{1)}$ 、浅田弘法 ${ }^{1)}$ 、鈴木光明 ${ }^{1)}$ 、吉村泰典 ${ }^{1)}$ 、木挽貢慈 ${ }^{2)}$

\section{Introduction of Laparoscopic Sacrocolpopexy at Our Hospital and Device for Preventing Complications}

Takashi Nagai ${ }^{1)}$, Wakana Bekku ${ }^{1)}$, Yukiko Mukouda ${ }^{1)}$, Keiko Sasaki ${ }^{1)}$, Takako Mashiko ${ }^{1)}$, Hirotaka Nakamura ${ }^{1)}$, Satsuki Okuno ${ }^{1)}$, Miwa Sato ${ }^{1)}$, Satoshi Asai ${ }^{1)}$, Shuichiro Hara ${ }^{1)}$,

Hitomi Tsukada $^{1)}$, Shuji Takemoto ${ }^{1)}$, Hiroto Tajima ${ }^{1)}$, Hironori Asada ${ }^{1)}$, Mitsuaki Suzuki ${ }^{1)}$,

Yasunori Yoshimura $^{1)}$, Koji Kobiki ${ }^{2)}$

Department of Obstetrics and Gynecology, Shin-Yurigaoka General Hospital ${ }^{1}$, Shin-Kawasaki Kobiki Women's clinic ${ }^{2)}$

\begin{abstract}
Laparoscopic sacrocolpopexy (LSC) provides patients with a safe and low relapse-rate procedure for Pelvic Organ Prolapse (POP), and a shift has been observed from traditional vaginal surgery to laparoscopic surgery in our hospital. From March 2015 to September 2016, 25 cases with POP underwent LSC after an uterus subtotal hysterectomy was performed, which fixed the double mesh suture of the vaginal wall and the L5 anterior longitudinal ligament. Upon introduction, patient's age, comorbidities, and lower urinary tract disorders were evaluated preoperatively to determine the adaptation by the appropriate questionnaire, Core Lower urinary tract Symptom Score (CLSS) and International Consultation on Incontinence Questionnaire-Short Form (ICIQ-SF). Surgical manipulation in the pouch of Douglas seems to be a rate-limiting step of surgery. Identification of the Levator ani muscles is crucial for accurate recognition of the pelvic floor midline, including the rectum, by appropriate towing. In addition, this stage is also important to prevent the complications of de novo defecation disorders.
\end{abstract}

Key words: Laparoscopic sacrocolpopexy, complications, defecation disorder

\section{【諸言】}

2014年 4 月の腹腔鏡下膀胱脱手術の保険収載以 降、子宮脱・膀胱瘤に対する腹腔鏡手術の適用が 本邦でも拡大しつつある。また2016年 4 月からの 腹腔鏡下仙骨胵固定術 (laparoscopic sacrocolpopexy、LSC）の保険点数の設定及びそ の流通は、従来法に比較して再発率の低い術式と して患者に恩恵があると考える ${ }^{1)}$ 。当院の骨盤臓 器脱 (Pelvic Organ Prolapse, POP) に対する術 式の選択も、2015年以降、従来の胵式手術から腹 腔鏡手術へと大きくシフトし（図 1)、2015年 3

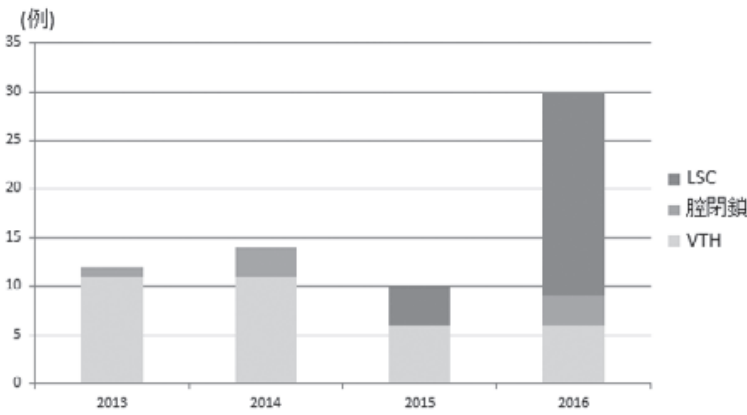

図 1 POPに対する術式の年次推移 
月から2016年 9 月までLSC25例を施行した。術式 は腹腔鏡下のダブルメッシュ法であり ${ }^{2)}$ 、症例は いずれも子宮亜全摘、前後胵壁へのメッシュ縫合 とL5前縦勒带への固定である。導入にあたって、 年齢・併存症 - 下部尿路障害の術前評価、特に術 後に増悪する可能性のある腹圧性尿失禁のスクリ ーニングが重要であると考え、適切な質問票 CLSSおよびICIQ-SFにより適応疾患を決定して いる。また、膀胱cineMRIによる画像評価を行い 手術成績の蓄積に努めている。ダグラス窩の展開 は運針と同様に手術の律速段階になると思われ る。ダグラス窩展開から肛門挙筋の同定において 重要な事は、適切な牽引による直腸・仙骨子宮勒 帯を含めた骨盤底正中の正確な認識であり、また、 この段階はメッシュの留置位置にも関係し、便秘 あるいは閉塞性排便障害の合併症予防の観点から も重要であると考える。

\section{【方 法】}

2015年 3 月から2016年 9 月まで、統一した術式 にてLSC25例を施行した。患者選択にあたり、質 問票にてPOPの主要症状を把握し、手術希望の場 合には術前後にMRIによる画像評価を行った。 LSCの適応を原則75歳未満とし、POP-Q stage II 以上かつCLSSにて過活動膀胱あるいは排尿障害 を主訴とする場合、尿失禁がある症例にはICIQSFにて混合性尿失禁または切迫性尿失禁を主訴 とする場合、また下垂脱出感のみでも手術希望の 場合、以上の症例で糖尿病などの合併症コントロ ールが良好な症例を選択している（図 2)。

術式は術前のユーテリンマニピュレーター ${ }^{\circledR}$
(ジョンソン・エンド・ジョンソン, 日本）の挿入、 気腹法、ダイヤモンド型のトロッカー配置を基本 とし、臍部 $12 \mathrm{~mm}$ 、正中 ・ 右下腹部 $5 \mathrm{~mm}$ 、左下 腹部 $12 \mathrm{~mm}$ のトロッカーを留置する。使用する機 器はモノポーラー、バイポーラー、BiClamp ${ }^{\circledR}$ （Erbe、USA）である。術式の手順を図 3 に示す。 全例で術後 2 日目に膀胱カテーテル抜去し、残 尿測定を行っている。残尿50cc未満で終了とし、 $50 \mathrm{cc}$ 以上なら 4 時間毎に導尿を継続し、場合によ りカテーテル再留置も考慮した。

\section{【手術成績】}

全25例の手術成績を表 1 に示す。年齢66歳（中 央值、range 48-71)、手術時間185分（145$257)$ 、出血量 $20 \mathrm{ml}(5-300)$ 、術後新規発症の腹 圧性尿失禁 $12.0 \%$ 、同様に便秘 $16.0 \%$ であった。併 存症は子宮筋腫 4 例、卵巣腫瘍 2 例、子宮内膜症 2 例であり、筋腫併存例では出血量が多い傾向に あった。解剖学的にはPOP-Q 1 以下を成功と定義 すれば、術後 3 か月経過の時点では成功率 $100 \%$ であった。また、同様に同時点でメッシュびらん の発症も無い。合併症は膀胱損傷 1 例であり、 1 期的に修復し 1 週間のカテーテル留置の後、退院 し後遺障害は無い。術後の残尿測定においてカテ ーテル再留置した症例は無く、排尿障害のある全 ての症例で術後に自覚症状の改善を認めた。25例 中 4 例で新規発症の便秘を訴え、内 1 例は閉塞性 排便障害と思われる症状を呈し、3 3 月経過後も 症状が持続している。

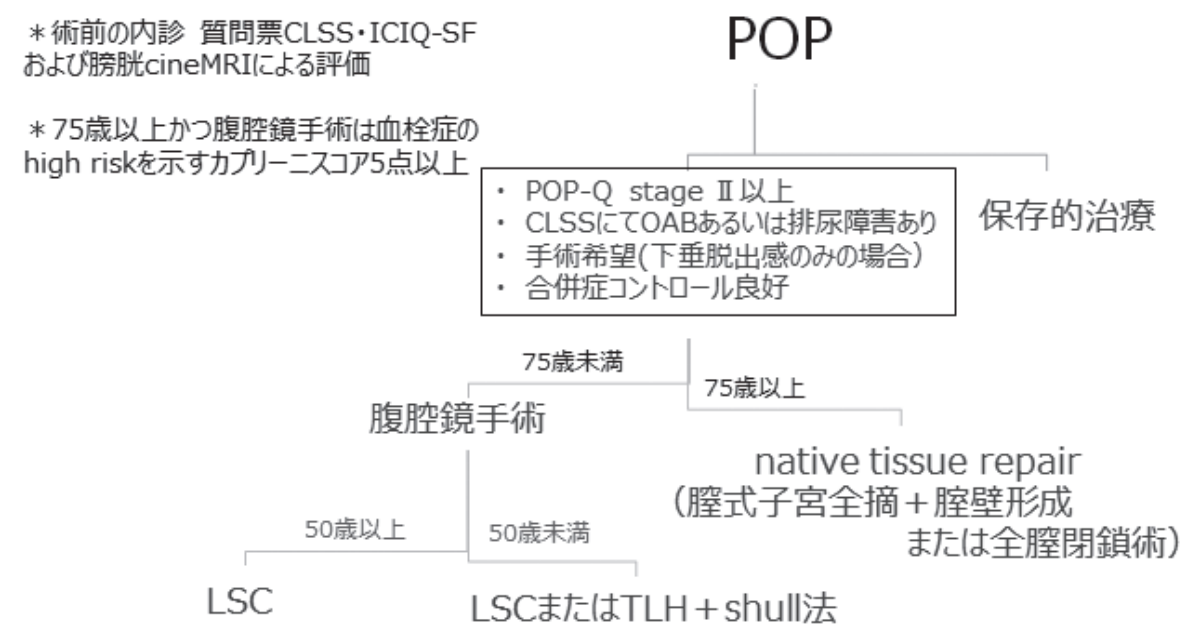

図2 POPにおける手術適応の選択 


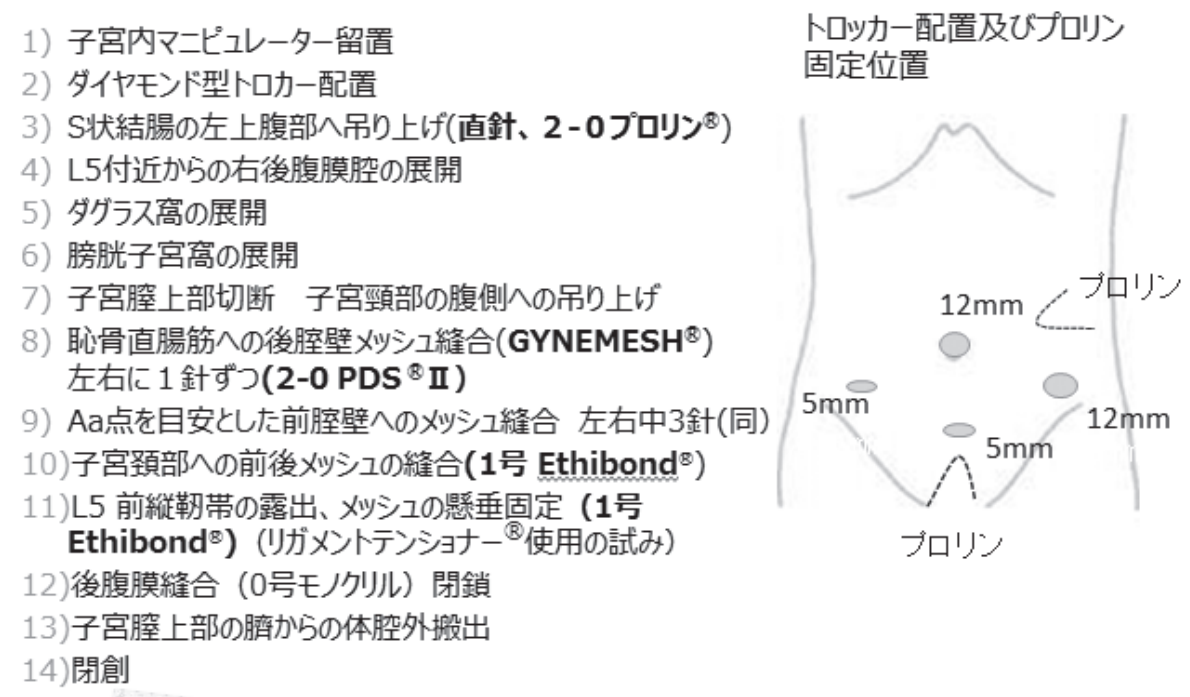

図３当院におけるLSC術式

表 1 LSCの手術成績

\begin{tabular}{|c|c|c|c|c|c|c|c|c|c|c|}
\hline \begin{tabular}{|l|}
$\mathrm{LSC}$ \\
$\mathrm{N}=25$
\end{tabular} & $\begin{array}{l}\text { 年齢 } \\
\text { (城) }\end{array}$ & \begin{tabular}{|l|} 
BMI \\
$(\mathrm{kg} / \mathrm{m} 2)$ \\
\end{tabular} & \begin{tabular}{|l|l|l} 
& 術前 \\
POP-Q
\end{tabular} & $\begin{array}{l}\text { 術前 } \\
\text { Ba点 }\end{array}$ & \begin{tabular}{|l} 
術後 \\
Ba点
\end{tabular} & 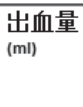 & \begin{tabular}{|l|}
$\begin{array}{l}\text { 手術時間 } \\
\text { (分) }\end{array}$ \\
\end{tabular} & 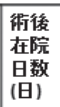 & 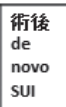 & $\begin{array}{l}\text { 術後 } \\
\text { de } \\
\text { novo } \\
\text { 便秘 }\end{array}$ \\
\hline $\begin{array}{c}\text { Media } \\
n\end{array}$ & 66 & 23.2 & 2 & \pm 0 & -4 & 20 & 185 & 4 & $12 \%$ & $16 \%$ \\
\hline Range & $\begin{array}{l}(48- \\
71)\end{array}$ & $\begin{array}{l}(18.2- \\
30.4)\end{array}$ & $(2-4)$ & $(-3-4)$ & $\begin{array}{l}(-3-2 \\
-5)\end{array}$ & $(5-300)$ & $(145-257)$ & (4-7) & & \\
\hline
\end{tabular}

\section{【考察】}

年齢による手術適応の制限は、手術が長時間に 及び血栓症のリスクを考慮したものであり、特に 75歳以上かつ腹腔鏡手術45分を超える場合は血检 症の診断スコアであるカプリーニスコア 5 点以上 (high risk) の項目となり、術後の抗凝固薬も検 討されることから一つの目安としている ${ }^{3)}$ 。図 2 に示す通り、75歳以上の症例に対しては基本的に、 手術時間が短く、必ずしも全身麻酔を必要としな いnative tissue repairを選択している。また、50 歳未満など若年層にメッシュ固定をするかどうか に関しては議論の分かれるところであろう。将来 的にポリプロピレンメッシュに替り、さらに改良 された固定器材の出現や術式自体が変化する可能 性もあり、慎重になるべきであると考える。当院 では50歳未満でも膀脱瘤を併発しない症例に対し ては、メッシュを使用しない腹腔鏡による子宮全 摘と仙骨子宮勒帯の臸断端固定に留める術式も考 慮している4)。

前腔壁のみでなく、後腟壁にもメッシュを留置 する意義に関しては未だ議論されている問題であ る。1992年にDeLanceyが示した臸管の支持機構
において 5 、 level 1 の子宮䅡部の垂直方向への懸 垂、level 2の臸上部2/3の固定による前後䶭壁の 接着、level 3の会陰部出口の癒合の内、LSCによ り改善効果が期待できるのはlevel 1 とlevel 2 で あると考える。特にlevel 2に扔いて、腹圧に抗す る羽蓋弁構造を維持するために6)、メッシュを前 後に留置する事により、前後膣壁を互いに平行に 保つ方が効果的であろうと考えるのは自然であ る。しかし、運針を肚門挙筋群のどの筋肉に行う かも重要な要素である。直腸に最も近接するのは 恥骨直腸筋であるが、合併症を避けるためより外 側に固定した方が、術後の便秘などを予防するた めに安全である可能性がある。

術後発症の腸管合併症に関しては、Ganatraら のreviewにて便秘や閉塞性排便障害、肛門痛、 便失禁も含めて $9.8 \%$ であり、ほとんどの症状は 術後 6 か月程度で軽快すると報告している7)。排 便のメカニズムについて図 4 に示す ${ }^{8)}$ 。排便にお いては内肛門括約筋の弛緩 (不随意筋、骨盤内臓 神経支配、S2-4）及び恥骨直腸筋の弛緩（随意筋、 㓌部神経支配）による直腸肛門角の開大が必要で ある。閉塞性排便障害を呈した症例の訴えとして は、「便が肛門付近まで来ているのに出づらく、 


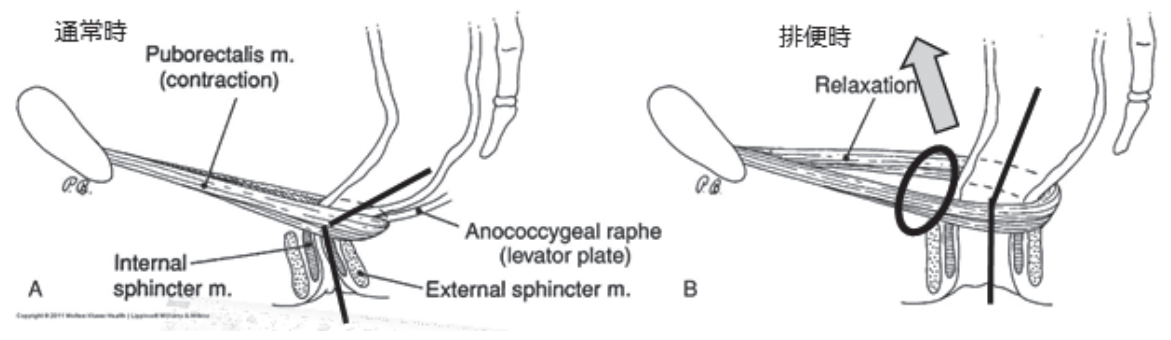

図4 閉塞性排便障害のメカニズムとメッシュ毫引方向 $(\Rightarrow)$

会院部あたりを押すと出やすくなる」というもの であり、図 4 に鑑みればその訴えも理解できる。 後腟壁メッシュの固定位置あるいは旁引過剩が、 直腸肛門角の開大を阻害する可能性があり、今後 の検討課題である。また、肛門挙筋周囲剥離の際 の神経損傷による可能性も否定できないため、同 部位の展開の際には熱損傷は最低限に留めるよう 注意すべきである。

後腹膜の展開において、特に我々が注意してい る点は、適切な牽引をかけ良好な視野を確保し、 適切な位置にメッシュを留置する事である。この ためには、後腟壁展開時には子宮頸部へのプロリ ン運針による腹側への毫引と助手による直腸の頭 側への毫引、前腟壁展開時には膀胱漿膜のプロリ ン運針による腹側への牽引と助手による子宮䅡部 の頭側への毫引が重要である。これにより仙骨子 宮勒帯が明瞭に露出され、展開すべき腔と留置す べき位置を正しく認識できる。斢引が十分行われ 直腸の走行が確認されれば、直腸腟間隙から肛門 挙筋群を露出するための腔は粗な結合組織のた め、腸把持鉗子等の鈍な鉗子にて腟壁に沿って容 易に展開できる。これは膀胱子宮窩においても同 様である。この際には胵壁は十分薄く、内診にて Aa点を確認しながら行う事ができる。メッシュ を留置する位置は、仙骨子宮勒带の外側に沿い、 尿管との距離を十分保った位置が理想であると考 える。また、勒帯の内側はS2、S3、S4神経幹と 近接するためなるべく避けるべきであると考え $る^{9)}$ 。さらに、直腸と仙骨子宮勒帯の間にメッシ 工を置いた場合には癒着により直腸の走行が変化 してしまう可能性がある。メッシュ留置後の所見 としては、ダグラス窩が骨盤底に埋没せずに形成 されている状態が望ましいと考える。これは、直 腸腟間隙より頭側では直腸からなるべく外側で後 腹膜展開をする事を意味する（図 5 ）。

右利きの術者が、術中に左手持針器を使用した 方が安全に運針できる局面がある。特に前縦勒帯 に運針する場合である。後腹膜血管の破格の多彩
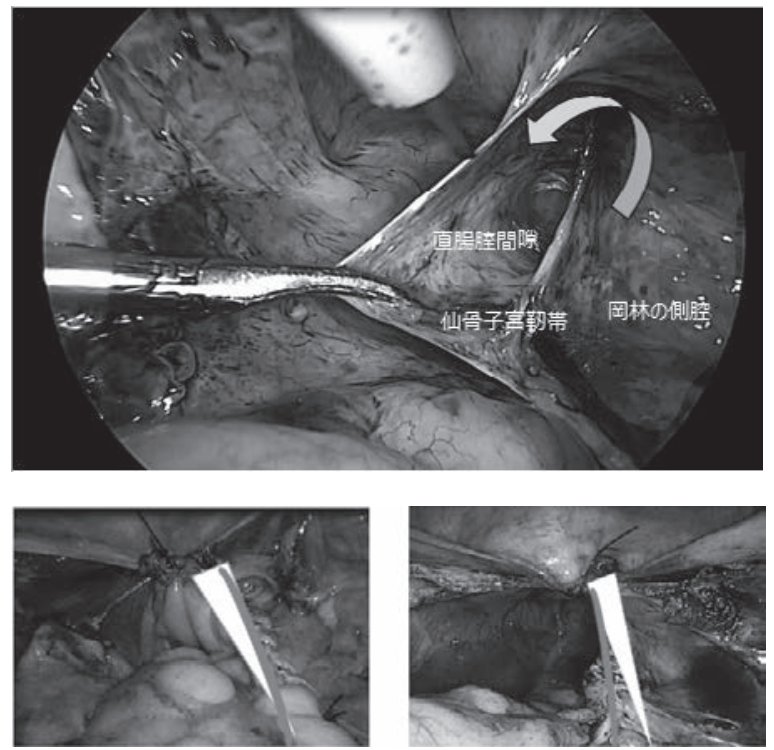

図 5 ダグラス窩の展開（上図）及び術後のメッシュの留置位置と 仙骨子宮勒帯との位置関係 (下左 ; 排便障害例、右下 ; 合併 症無し、灰色：仙骨子宮勒帯、白色：メッシュ）

さは、これまでに多数報告がある ${ }^{10)}$ 。術前の破格 の診断目的には3D-CTによる検査も有用な方法で はある ${ }^{11)}$ 。しかし、前縦勒帯における運針の際に 注意すべき破格はleft IVCでその頻度は $0.2 \%$ 程度 であり、必ずしも行うべきとは言えない。当院で はカメラポートの設置後に、最初にL5周囲に運 針できるスペースがあるかどうかを確認してい る。患者には常に、LSCが困難な場合の経腟手術 への切り替えの可能性に関して、インフォームド コンセントを得ている。

腟壁へのメッシュ固定に際して、縫合糸の選択 として吸収糸と非吸収糸の選択に関する議論もあ る。当院では腟壁へのメッシュ露出によるびらん を危惧し遅延性吸収糸を使用している。 Shepherdらによれば、非吸収糸群161例と遅延性 吸収糸群254例の術後 6 週間の比較で腟壁びらん の頻度が有意に少なく（3.7\%対 $0 \% 、 \mathrm{p}=0.002 ） 、$ 手術成績は同等であったとの報告があり ${ }^{12)}$ 、当院 でも腟壁への縫合糸に関する成績の比較を検討し ている。 
手術成績の客観的な評価として、内診所見以外 には尿流動態検查およびMRIによる画像評価が挙 がる。矢状断における恥骨尾骨ラインを基準とし た膀胱と子宮頸部、尿道位置の正確な解剖学的是 正が、本手術の主要な要素になりうるし、同時に 合併症予防のアプローチにつながる可能性があ る。しかし、現状では手術成績とMRIによる評価 を合わせた文献は少ない。今後、症例を重ねて検 討してゆきたいと考える。

これまで内診を頼りに主観的な感覚で行ってい た前縦勒帯へのメッシュ铈引力を数值化すること は、安定したより良い手術成績を目指す上で有用 であると考える。しかし、婦人科用に開発された 率引力測定機器は現在のところ存在しない。リガ メントテンショナー ${ }^{\circledR}$ (Aimedic MMT, 日本) は 整形外科領域にて勒帯再建用の術中牽引力測定機 器であり、当院ではメッシュ固定の際の牽引力を この機器により測定し、一定した術式の確立を目 指して評価を試みている（図6）。

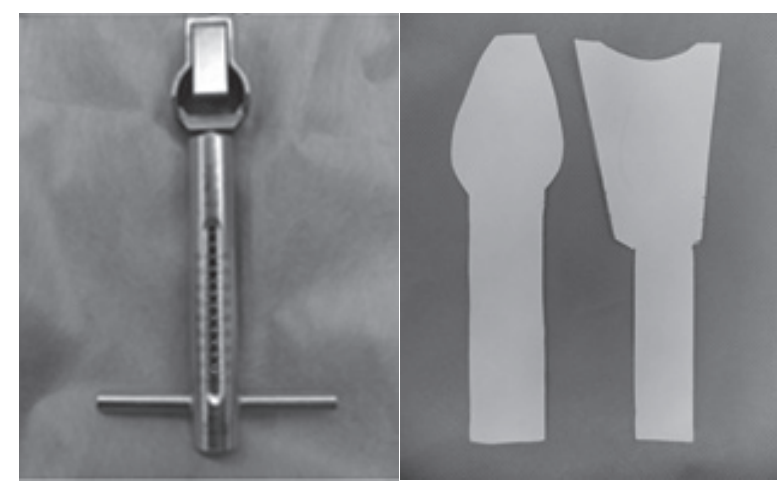

図 6 リガメントテンショナー ${ }^{\circledR}$ とメッシュ用型紙（左;前腟壁用、右; 後胵壁用)

ポリプロピレンメッシュが仙骨子宮勒带の代替 えとなりうるかに関して、Ramanahらによる Cardinal ligament及びuterosacral ligamentに関 する50の関連文献のreviewは大変興味深い ${ }^{13)}$ 。そ の中でBullerらによれば、cadaverにおいて解剖 学的に仙骨子宮勒帯は勒帯長 $8.7 \mathrm{~cm} \quad(95 \%$ CI 7.5 - 10.0)、子宮䅡部坐骨棘レベルでは重量 $>17 \mathrm{~kg}$ を支持できるが、仙骨レベルでは $5 \mathrm{~kg}$ 未満しか 支持できない構造物であり ${ }^{14)}$ 、Campbellらによ れば病理学的に頚部付近 $1 / 3$ は密な平滑筋線維、 中 $1 / 3$ は結合組織主体、仙骨側 $1 / 3$ は粗な結合組織 と血管・神経である ${ }^{15)}$ 。すなわちUSLはCLと異 なり、平滑筋線維を十分含む構造物であるが、 CL も USL も共に skeletal ligamentではなく visceral ligamentであると指摘している。
Visceral ligamentは脈管・神経・結合組織・脂肪 組織の含有量が場所により異なり、かつ臓器と体 壁をつなぐ腸間膜様構造物であるとしている。整 形外科領域で対象とする均一な骨格筋の勒带とは 異なるため、メッシュの固定により、膀胱直腸の 可動性・柔軟性が失われる可能性を常に考慮しな がら本手術に臨むべきであると考える。

\section{【結 語】}

LSCにおける手術の安全性を考える場合に、特 に肛門挙筋の展開において重要なことは直腸・仙 骨子宮勒帯の位置を含めた正中の正確な認識であ ると考えられた。今後も症例を積み重ねて、合併 症、特に腹圧性尿失禁や排便障害の予防に関わる 因子の模索、術式の改良に努める。

本論文の要旨は第56回日本産婦人科内視鏡学会 にて発表した。

\section{【参考文献】}

1) Maher C, et al.: Surgical management of pelvic organ prolapse in women (Review). Cochrane Database Syst Rev 2013 ; Apr 30 (4).

2) Laparoscopic sacrocolpopexy with two separate meshs along the anterior and posterior vaginal walls for multicompartment pelvic organ prolapse. J Am Assoc Gynecol Laparosc. 2004 ; 11 (1) : 29-35.

3 ) Gould M, et al.: Prevention of VTE in nonorthopedic surgical patients. Antithrombotic therapy and prevention of thrombosis, $9^{\text {th }} \mathrm{Ed}$ : American college of chest physicians evidenced-based clinical practice guidelines. Chest $2012 ; 141: 227-277$.

4 ) 西村和明、他.：骨盤臓器脱に対する腹腔鏡下腔断端 仙骨子宮勒帯固定術. 日産婦内視鏡学会誌 $2014 ; 30$ : 177-180.

5 ) DeLancey JO, et al.: Anatomic aspects of vaginal eversion after hysterectomy. Am J Obstet Gynecol 1992 ; $166: 1717-1724$.

6 ) 古山将康. : 婦人科疾患の診断 - 治療 - 管理 : 性器の 形態異常：位置異常.日産婦誌 $2009 ; 61 ： 27-46$.

7 ) Ganatra AM, et al.: The current status of laparoscopic sacrocolpopexy: A review. Euro Urology 2009 ; 55 : 1089-1105.

8) Aronson MP, Lee RA.: Te Linde`s Operative Gynecology. $10^{\text {th }}$ edition ; $40: 995-998$.

9 ) Siddique SA, Gutman RE, Schon Ybarra MA, Rojas F, Handa VL. Relationship of the uterosacral ligament to the sacral plexus and to the pudendal nerve. Int Urogynecol J Pelvic Floor Dysfunct. $2006 ; 17: 642-645$. 
10) Kose MF, et al.: Anormalies of major retroperitoneal vascular stricture. Int J Gynecol Cancer 2011 ; 21 : 1312-1319.

11) Gyimadu A, et al.: Retroperitoneal vascular aberrations increase the risk of vascular injury during lymphadenectomy in gynecologic cancers. Arch Gynecol Obstet 2012 ; 286 : 449-455.

12) Shepherd JP, et al.: Effect of suture selection on the rate of suture or mesh erosion and surgery failure in abdominal sacrocolpopexy. Female Pelvic Med Reconstr Surg 2010 ; 16 : 229-33.

13) Ramanah R, et al.: Anatomy and histology of apical Support : a literature review concerning cardinal and uterosacral ligaments. Int Urogynecol J 2012 ; $23: 1483-1494$.

14) Buller JL, Thompson JR, Cundiff GW, Krueger Sullivan L, Schon Ybarra MA, Bent AE. Uterosacral ligament: description of anatomic relationships to optimize surgical safety. Obstet Gynecol. 2001 ; 97 : 873-879.

15) Campbell RM. The anatomy and histology of the sacrouterine ligaments. Am J Obstet Gynecol. 1950 ; 59 : 1-12. 